\title{
Possible Role of Inadequate Quantities of Intra-Thyroidal Cobalt, Rubidium and Zinc in the Etiology of Female Subclinical Hypothyroidism
}

\author{
Vladimir Zaichick ${ }^{1 *}$ and Sofia Zaichick ${ }^{1,2}$ \\ ${ }^{1}$ Radionuclide Diagnostics Department, Medical Radiological Research Centre, \\ Russia \\ ${ }^{2}$ Laboratory of Dr. Gabriela Caraveo Piso, Feinberg School of Medicine, \\ Northwestern University, USA
}

\section{Research Article \\ Volume 2 Issue 1}

Received Date: January 20, 2018

Published Date: February 21, 2018

DOI: $10.23880 /$ whsj- 16000108

*Corresponding author: V. Zaichick, Korolyev St. 4, MRRC, Obninsk 249036, Kaluga region, Russia, Tel: +7 (48439) 60289; Fax: +7 (495) 956 1440; E-mail: vezai@obninsk.com

\section{Abstract}

Background: Subclinical hypothyroidism does affect fertility. The prevalence of subclinical hypothyroidism is $10-15$ times more common in women than in men. Trace elements play important roles in thyroid function and fertility.

Objective: The aim of this exploratory study was to evaluate whether significant differences of trace element contents exists between female and male thyroids and how they can be related to the etiology of subclinical hypothyroidism.

Methods: Thyroid tissue levels of ten trace elements: silver, cobalt, chromium, iron, mercury, rubidium, antimony, scandium, selenium, and zinc were prospectively evaluated in 105 healthy persons (33 females and 72 males) Measurements were performed using instrumental neutron activation analysis with high resolution spectrometry of long-lived radionuclides. Tissue samples were divided into two portions. One was used for morphological study while the other was intended for trace element analysis.

Results: It was found that content of cobaltin thyroid of females was significantly higher than that of males, while contents of rubidiumand zinc were lower.

Conclusions: Inappropriate content of intra-thyroidal cobalt, rubidiumand zinc can be associated with the etiology of female subclinical hypothyroidism.

Keywords: Subclinical hypothyroidism; Female Thyroid; Trace Elements; Neutron activation analysis

Abbreviations: SCH: Subclinical Hypothyroidism; TE: Trace Elements; INAA-LLR: Neutron Activation Analysis with High Resolution Spectrometry of Long-
Lived Radionuclides Fluorescent Analysis; SRM: Standard Reference Material; CRM: Certified Reference Material; BSS: Biological Synthetic Standards. 


\section{Women's Health Science Journal}

\section{Introduction}

Adequate thyroid function is important to maintain normal reproduction, because thyroid dysfunction affects fertility in various ways resulting in abnormal ovulatory cycles, luteal phase defects, high prolactin levels, and sex hormone imbalances [1,2]. Therefore, normal thyroid function is necessary for fertility, and to sustain a healthy pregnancy [2]. From large population studies, which measured thyroid function, and systematic reviews of this subject carried out in the 1990 s to 2010s, it is known that untreated hypothyroidism is a common condition all over the world [2-10]. The prevalence of subclinical hypothyroidism $(\mathrm{SCH})$ is between $1 \%$ and $10 \%$ in different countries [2-10] and almost everywhere it is 10-15 times more common in women than in men $[2,4,9]$. Form such a great gender-related difference in the prevalence of $\mathrm{SCH}$ arises a question about a specific sensitivity of female thyroid tissue to some external and internal factors.

Although the etiology of SCH and other thyroidal disorders is unknown in detail, several risk factors including deficiency or excess of such micronutrients as iodine (I) has been well identified [11-22]. Besides I involved in thyroid function, other trace elements (TE) also play important roles such as stabilizers, structural elements, maintenance and regulation of cell function, gene regulation, enzyme cofactors, activation or inhibition of enzymatic reactions, normal peripheral utilization of thyroid hormones and regulation of cell membrane function [23]. Essential or toxic properties of TE depend on tissue-specific need or tolerance, respectively [24]. Both TE deficiencies as well as overexposures may disturb the thyroidal cell functions [24].

The reliable data on TE mass fractions in normal human thyroid separately for female and male gland is apparently extremely limited. There are a few studies regarding TE content in human thyroid, using chemical techniques and instrumental methods [25-35]. However, the majority of these data are based on measurements of processed tissue and in many studies tissue samples are ashed before analysis. In other cases, thyroid samples are treated with solvents (distilled water, ethanol etc) and then are dried at a high temperature for many hours. There is evidence that certain quantities of TE are lost as a result of such treatment [36-38]. Moreover, only a few of these studies employed quality control using certified/standard reference materials (CRM/SRM) for determination of the TE mass fractions. Sample-nondestructive technique such as instrumental neutron activation analysis with high resolution spectrometry of long-lived radionuclides (INAA-LLR) is good alternatives for multi- element determination in the samples of thyroid parenchyma.

This work had three aims. The primary purpose of this study was to determine reliable values for such TE as silver $(\mathrm{Ag})$, cobalt $(\mathrm{Co})$, chromium $(\mathrm{Cr})$, iron $(\mathrm{Fe})$, mercury $(\mathrm{Hg})$, rubidium $(\mathrm{Rb})$, antimony $(\mathrm{Sb})$, scandium $(\mathrm{Sc})$, selenium (Se), and zinc (Zn) contents in intact (normal) thyroid gland of apparently healthy persons using INAA-LLR analysis. The second aim was to compare the levels of TE in the thyroid tissue of all females and males investigated in the study. The final aim was to compare the levels of TE in the thyroid tissue of females and males in age group 1 ( $\leq 40$ years) and in age group 2 ( $>40$ years).

All studies were approved by the Ethical Committees of the Medical Radiological Research Centre, Obninsk.

\section{Material and Methods}

Samples of the human thyroid were obtained from randomly selected autopsy specimens of 33 females (European-Caucasian, aged 3.5 to 87 years) and 72 males (European-Caucasian, aged 2.0 to 80 years). All the deceased were citizens of Obninsk and had undergone routine autopsy at the Forensic Medicine Department of City Hospital, Obninsk. Age ranges for subjects were divided into two age groups, with group 1 ( $\leq 40$ years), and group 2 ( $>40$ years). For females in group $1(\mathrm{n}=11)$ mean age ( \pm standard error of mean, SEM) was $30.9 \pm 3.1$ years and in group $2(n=22)$ mean age was $66.3 \pm 2.7$ years. For males in group $1(n=36)$ mean age was $22.5 \pm 1.4$ years and in group $2(n=36)$ mean age was $52.4 \pm 2.4$ years. These groups were selected to reflect the condition of thyroid tissue in the children, teenagers, young adults and first period of adult life (group 1) and in the second period of adult life as well as in old age (group 2). The available clinical data were reviewed for each subject. None of the subjects had a history of an intersex condition, endocrine disorder, or other chronic disease that could affect the normal development of the thyroid. None of the subjects were receiving medications or used any supplements known to affect thyroid trace element contents. The typical causes of sudden death of most of these subjects included trauma or suicide and also acute untreated illness (cardiac insufficiency, stroke, embolism of pulmonary artery, alcohol poisoning).

All right lobes of thyroid glands were divided into two portions using a titanium scalpel [39]. One tissue portion was reviewed by an anatomical pathologist while the other was used for the ChE content determination. A histological examination was used to control the age norm conformity as well as the unavailability of microadenomatosis and latent cancer. 
After the samples intended for TE analysis were weighed, they were freeze-dried and homogenized [4042]. The pounded sample weighing about50 mg was used for trace element measurement by INAA-LLR. The samples for INAA-LLR were wrapped separately in a high-purity aluminum foil washed with rectified alcohol beforehand and placed in a nitric acid-washed quartz ampoule.

To determine contents of the TE by comparison with a known standard, biological synthetic standards (BSS) prepared from phenol-formaldehyde resins were used [43]. In addition to BSS, aliquots of commercial, chemically pure compounds were also used as standards. Ten certified reference material IAEA H-4 (animal muscle) and IAEA HH-1 (human hair) subsamples weighing about $50 \mathrm{mg}$ were treated and analyzed in the same conditions that thyroid samples to estimate the precision and accuracy of results.

A vertical channel of nuclear reactor was applied to determine the content of $\mathrm{Ag}, \mathrm{Co}, \mathrm{Cr}, \mathrm{Fe}, \mathrm{Hg}, \mathrm{Rb}, \mathrm{Sb}, \mathrm{Sc}, \mathrm{Se}$, and $\mathrm{Zn}$ by INAA-LLR. The quartz ampoule with thyroid samples, standards, and certified reference material was soldered, positioned in a transport aluminum container and exposed to a 24-hour neutron irradiation in a vertical channel with a neutron flux of $1.3 \cdot 10^{13}$ $\mathrm{n} \cdot \mathrm{cm}^{-2} \cdot \mathrm{s}^{-1}$. Ten days after irradiation samples were reweighed and repacked.

The samples were measured for period from 10 to 30 days after irradiation. The duration of measurements was from $20 \mathrm{~min}$ to 10 hours subject to pulse counting rate. The gamma spectrometer included the $100 \mathrm{~cm}^{3} \mathrm{Ge}$ (Li) detector and on-line computer-based MCA system. The spectrometer provided a resolution of $1.9 \mathrm{keV}$ on the ${ }^{60} \mathrm{Co} 1332 \mathrm{keV}$ line. Details of used nuclear reactions, radionuclides, and gamma-energies were presented in our earlier publications concerning the INAA chemical element contents in human prostate and scalp hair [4448].

A dedicated computer program for INAA mode optimization was used [49]. All thyroid samples were prepared in duplicate, and mean values of TE contents were used in final calculation. Using Microsoft Office Excel software, a summary of the statistics, including, arithmetic mean, standard deviation, standard error of mean, minimum and maximum values, median, percentiles with 0.025 and 0.975 levels was calculated for TE contents in thyroid tissue samples of females and males. The difference in the results between females and males (age group 1 and 2 combined), as well as between females and males separately in age group 1 and group 2 was evaluated by the parametric Student's $t$-test and non-parametric Wilcoxon-Mann-Whitney $U$ test.

\section{Results}

(Table 1) depicts our data for $\mathrm{Ag}, \mathrm{Co}, \mathrm{Cr}, \mathrm{Fe}, \mathrm{Hg}, \mathrm{Rb}$, $\mathrm{Sb}, \mathrm{Sc}, \mathrm{Se}$, and $\mathrm{Zn}$ mass fractions in ten sub-samples of IAEA H-4 (animal muscle) and IAEA HH-1 (human hair) certified reference material and the certified values of this material.

\begin{tabular}{|c|c|c|c|c|}
\hline \multirow{2}{*}{ Element } & IAEA H-4 animal muscle & This work results & IAEA HH-1 human hair & This work results \\
\cline { 2 - 5 } & $\mathbf{9 5 \%}$ confidence interval & $\mathbf{M} \pm$ SD & $\mathbf{9 5 \%}$ confidence interval & M \pm SD \\
\hline $\mathrm{Ag}$ & - & $0.033 \pm 0.008$ & $0.19^{\mathrm{b}}$ & $0.18 \pm 0.05$ \\
\hline $\mathrm{Co}$ & $0.0027^{\mathrm{b}}$ & $0.0034 \pm 0.0008$ & $5.97 \pm 0.42^{\mathrm{a}}$ & $5.4 \pm 1.1$ \\
\hline $\mathrm{Cr}$ & $0.06^{\mathrm{b}}$ & $0.071 \pm 0.010$ & $0.27^{\mathrm{b}}$ & $\leq 0.3$ \\
\hline $\mathrm{Fe}$ & $49.1 \pm 6.5^{\mathrm{a}}$ & $47.0 \pm 1.0$ & $23.7 \pm 3.1^{\mathrm{a}}$ & $25.1 \pm 4.3$ \\
\hline $\mathrm{Hg}$ & $0.014^{\mathrm{b}}$ & $0.015 \pm 0.004$ & $1.70 \pm 0.09^{\mathrm{a}}$ & $1.54 \pm 0.14$ \\
\hline $\mathrm{Rb}$ & $18.7 \pm 3.5^{\mathrm{a}}$ & $23.7 \pm 3.7$ & $0.94^{\mathrm{b}}$ & $0.89 \pm 0.17$ \\
\hline $\mathrm{Sb}$ & $0.0056^{\mathrm{b}}$ & $0.0061 \pm 0.0021$ & $0.031^{\mathrm{b}}$ & $0.033 \pm 0.009$ \\
\hline $\mathrm{Sc}$ & $0.0059^{\mathrm{b}}$ & $0.0015 \pm 0.0009$ & - & - \\
\hline $\mathrm{Se}$ & $0.28 \pm 0.08^{\mathrm{a}}$ & $0.281 \pm 0.014$ & $0.35 \pm 0.02^{\mathrm{a}}$ & $0.37 \pm 0.08$ \\
\hline $\mathrm{Zn}$ & $86.3 \pm 11.5^{\mathrm{a}}$ & $91 \pm 2$ & $174 \pm 9^{\mathrm{a}}$ & $173 \pm 17$ \\
\hline
\end{tabular}

Table 1: Neutron activation analysis data of trace element contents in certified reference material IAEA H-4 (animal muscle) and IAEA HH-1 (human hair) compared to certified values ((mg/kg, dry mass basis).

$\mathrm{M}$ - arithmetical mean, SD - standard deviation, a - certified values, $\mathrm{b}$ - information values.

(Table 2) presents certain statistical parameters (arithmetic mean, standard deviation, standard error of mean, minimal and maximal values, median, percentiles with 0.025 and 0.975 levels) of the $\mathrm{Ag}, \mathrm{Co}, \mathrm{Cr}, \mathrm{Fe}, \mathrm{Hg}, \mathrm{Rb}$, $\mathrm{Sb}, \mathrm{Sc}, \mathrm{Se}$, and Znmass fractionin normal thyroid tissue of female and male. 
Women's Health Science Journal

\begin{tabular}{|c|c|c|c|c|c|c|c|c|c|}
\hline Gender & Element & M & SD & SEM & Min & Max & Median & P 0.025 & P 0.975 \\
\hline \multirow{10}{*}{$\begin{array}{l}\text { Males } \\
\mathrm{n}=72\end{array}$} & $\mathrm{Ag}$ & 0.0156 & 0.0155 & 0.0021 & 0.0017 & 0.08 & 0.0104 & 0.0018 & 0.0661 \\
\hline & Co & 0.0352 & 0.0234 & 0.0031 & 0.0046 & 0.124 & 0.0302 & 0.0113 & 0.101 \\
\hline & $\mathrm{Cr}$ & 0.52 & 0.286 & 0.041 & 0.13 & 1.3 & 0.414 & 0.152 & 0.98 \\
\hline & $\mathrm{Fe}$ & 222 & 96 & 12 & 51 & 487 & 221 & 76.1 & 432 \\
\hline & $\mathrm{Hg}$ & 0.0461 & 0.0391 & 0.0053 & 0.0091 & 0.18 & 0.0324 & 0.0102 & 0.15 \\
\hline & $\mathrm{Rb}$ & 7.89 & 4.56 & 0.58 & 2.24 & 29.4 & 6.86 & 2.73 & 18.2 \\
\hline & $\mathrm{Sb}$ & 0.108 & 0.076 & 0.01 & 0.0047 & 0.308 & 0.0965 & 0.0095 & 0.291 \\
\hline & Sc & 0.0051 & 0.0036 & 0.0012 & 0.0005 & 0.0118 & 0.0044 & 0.0007 & 0.0112 \\
\hline & $\mathrm{Se}$ & 2.36 & 1.34 & 0.17 & 0.53 & 5.8 & 1.96 & 0.804 & 5.7 \\
\hline & $\mathrm{Zn}$ & 103 & 43 & 5.5 & 34 & 221 & 94.6 & 40.5 & 200 \\
\hline \multirow{10}{*}{$\begin{array}{c}\text { Females } \\
n=33\end{array}$} & $\mathrm{Ag}$ & 0.014 & 0.0093 & 0.002 & 0.0012 & 0.0331 & 0.013 & 0.0021 & 0.0321 \\
\hline & Co & 0.0505 & 0.0322 & 0.0064 & 0.017 & 0.14 & 0.0405 & 0.0183 & 0.13 \\
\hline & $\mathrm{Cr}$ & 0.573 & 0.246 & 0.049 & 0.29 & 1.22 & 0.488 & 0.303 & 1.11 \\
\hline & $\mathrm{Fe}$ & 232 & 112 & 22 & 63 & 512 & 199 & 64.8 & 480 \\
\hline & $\mathrm{Hg}$ & 0.0329 & 0.0246 & 0.0051 & 0.0065 & 0.1 & 0.0263 & 0.0079 & 0.1 \\
\hline & $\mathrm{Rb}$ & 6.16 & 2.42 & 0.48 & 1.11 & 12.8 & 6.3 & 2.38 & 10.8 \\
\hline & $\mathrm{Sb}$ & 0.116 & 0.063 & 0.012 & 0.0115 & 0.248 & 0.108 & 0.0183 & 0.247 \\
\hline & Sc & 0.0042 & 0.004 & 0.0012 & 0.0002 & 0.0143 & 0.0032 & 0.0003 & 0.0124 \\
\hline & $\mathrm{Se}$ & 2.22 & 1.19 & 0.23 & 0.439 & 5.32 & 2.07 & 0.773 & 4.85 \\
\hline & $\mathrm{Zn}$ & 85.7 & 38 & 7.44 & 8.1 & 166 & 83 & 22.9 & 156 \\
\hline
\end{tabular}

Table 2: Some statistical parameters of Ag, Co, $\mathrm{Cr}, \mathrm{Fe}, \mathrm{Hg}, \mathrm{Rb}, \mathrm{Sb}, \mathrm{Sc}, \mathrm{Se}$, and Znmass fractions (mg/kg, dry mass basis) in normal thyroid tissue of females and males.

$\mathrm{M}$ - arithmetic mean, SD - standard deviation, SEM - standard error of mean, Min - minimum value, Max - maximum value, P 0.025 - percentile with 0.025 level, P 0.975 - percentile with 0.975 level.

The comparison of our results with published data for $\mathrm{Ag}$, $\mathrm{Co}, \mathrm{Cr}, \mathrm{Fe}, \mathrm{Hg}, \mathrm{Rb}, \mathrm{Sb}$, Sc, Se, and Znmass fraction

in normal human thyroid is shown in Table 3.

\begin{tabular}{|c|c|c|c|c|}
\hline \multirow[b]{2}{*}{ Element } & \multirow{2}{*}{$\begin{array}{c}\text { This work } \\
\begin{array}{c}\text { Males and females } \\
\mathrm{M} \pm \mathrm{SD}\end{array} \\
\end{array}$} & \multicolumn{3}{|c|}{ Published data [Reference] } \\
\hline & & \begin{tabular}{|c|} 
Median of means \\
(n)*
\end{tabular} & $\begin{array}{c}\text { Minimum of means } M \text { or } \\
M \pm S D,(n)^{* *}\end{array}$ & $\begin{array}{c}\text { Maximum of means M or } \\
M \pm S D,(n)^{* *}\end{array}$ \\
\hline $\mathrm{Ag}$ & $0.015 \pm 0.014$ & $0.25(12)$ & $0.000784(16)[26]$ & $1.20 \pm 1.24(105)[27]$ \\
\hline Co & $0.040 \pm 0.027$ & $0.34(17)$ & $0.026 \pm 0.031(46)[28]$ & $70.4 \pm 40.8(14)[29]$ \\
\hline $\mathrm{Cr}$ & $0.54 \pm 0.27$ & $0.69(17)$ & $0.105(18)[30]$ & $24.8 \pm 2.4(4)[31]$ \\
\hline $\mathrm{Fe}$ & $225 \pm 100$ & $252(21)$ & $56(120)[32]$ & $2444 \pm 700(14)[29]$ \\
\hline $\mathrm{Hg}$ & $0.042 \pm 0.036$ & $0.08(13)$ & $0.0008 \pm 0.0002(10)[33]$ & $396 \pm 40(4)[31]$ \\
\hline $\mathrm{Rb}$ & $7.4 \pm 4.1$ & $12.3(9)$ & $\leq 0.85(29)[33]$ & $294 \pm 191$ (14) [29] \\
\hline $\mathrm{Sb}$ & $0.111 \pm 0.072$ & $0.105(10)$ & $0.040 \pm 0.003(-)[34]$ & $4.0(-)[35]$ \\
\hline $\mathrm{Sc}$ & $0.0046 \pm 0.0038$ & $0.009(4)$ & $0.0018 \pm 0.0003(17)[36]$ & $0.0135 \pm 0.0045(10)[33]$ \\
\hline $\mathrm{Se}$ & $2.32 \pm 1.29$ & $2.61(17)$ & $0.95 \pm 0.08(29)[33]$ & $756 \pm 680(14)[29]$ \\
\hline $\mathrm{Zn}$ & $97.8 \pm 42.3$ & $118(51)$ & $32(120)[32]$ & $820 \pm 204(14)[29]$ \\
\hline
\end{tabular}

Table 3: Median, minimum and maximum value of means of $\mathrm{Ag}$, $\mathrm{Co}, \mathrm{Cr}, \mathrm{Fe}, \mathrm{Hg}, \mathrm{Rb}, \mathrm{Sb}$, Sc, Se, and $\mathrm{Zn}$ contents in normal thyroid according to data from the literature in comparison with our results (mg/kg, dry mass basis).

$\mathrm{M}$-arithmetic mean, SD - standard deviation, (n)* - number of all references, (n)** - number of samples.

The ratios of means and the difference between mean values $\mathrm{Ag}, \mathrm{Co}, \mathrm{Cr}, \mathrm{Fe}, \mathrm{Hg}, \mathrm{Rb}, \mathrm{Sb}, \mathrm{Sc}, \mathrm{Se}$, and $\mathrm{Zn}$ mass fractions in normal thyroid of females and males are presented in Table 4. Because, in our previous studies age-dependents of many TE in thyroid gland was found [50-53], the comparison between TE contents in thyroid of females and males separately in age group 1 and in age group 2 was also performed (Tables 4-6). 


\section{Women's Health Science Journal}

\begin{tabular}{|c|c|c|c|c|c|}
\hline \multirow{2}{*}{ Element } & \multicolumn{4}{|c|}{ Thyroid tissue } & Ratio \\
\cline { 2 - 6 } & Males 2.0-80 years n=72 & Females 3.5-87 years n=33 & Student's t-test p $\leq$ & U-test p & Females to Males \\
\hline $\mathrm{Ag}$ & $0.0156 \pm 0.0021$ & $0.0140 \pm 0.0020$ & 0.586 & $>0.05$ & 0.9 \\
\hline $\mathrm{Co}$ & $0.0352 \pm 0.0031$ & $0.0505 \pm 0.0064$ & $\mathbf{0 . 0 3 9}$ & $\leq \mathbf{0 . 0 1}$ & 1.43 \\
\hline $\mathrm{Cr}$ & $0.520 \pm 0.041$ & $0.573 \pm 0.049$ & 0.411 & $>0.05$ & 1.1 \\
\hline $\mathrm{Fe}$ & $222 \pm 12$ & $232 \pm 22$ & 0.692 & $>0.05$ & 1.05 \\
\hline $\mathrm{Hg}$ & $0.0461 \pm 0.0053$ & $0.0329 \pm 0.0051$ & 0.079 & $>0.05$ & 0.71 \\
\hline $\mathrm{Rb}$ & $7.89 \pm 0.58$ & $6.16 \pm 0.48$ & $\mathbf{0 . 0 2 4}$ & $\leq \mathbf{0 . 0 1}$ & 0.78 \\
\hline $\mathrm{Sb}$ & $0.108 \pm 0.010$ & $0.116 \pm 0.012$ & 0.649 & $>0.05$ & 1.07 \\
\hline $\mathrm{Sc}$ & $0.0051 \pm 0.0012$ & $0.0042 \pm 0.0012$ & 0.59 & $>0.05$ & 0.82 \\
\hline $\mathrm{Se}$ & $2.36 \pm 0.17$ & $2.22 \pm 0.23$ & 0.633 & $>0.05$ & 0.94 \\
\hline $\mathrm{Zn}$ & $103 \pm 5.5$ & $85.7 \pm 7.4$ & 0.069 & $\leq \mathbf{0 . 0 5}$ & 0.83 \\
\hline
\end{tabular}

Table 4: Differences between mean values (M $\pm \mathrm{SEM}$ ) of $\mathrm{Ag}, \mathrm{Co}, \mathrm{Cr}, \mathrm{Fe}, \mathrm{Hg}, \mathrm{Rb}, \mathrm{Sb}, \mathrm{Sc}, \mathrm{Se}$, and Znmass fraction (mg/kg, dry mass basis) in normal thyroid tissue of males and females.

M - arithmetic mean, SEM - standard error of mean, t-test - Student's t-test, U-test - Wilcoxon-Mann-Whitney U-test, Statistically significant values are in bold.

\begin{tabular}{|c|c|c|c|c|c|}
\hline \multirow{2}{*}{ Element } & \multicolumn{3}{|c|}{ Thyroid tissue } & Ratio \\
\cline { 2 - 6 } & Males (MG1) n=44 & Females (FG1) n=11 & Student's t-test $\mathbf{p} \leq$ & U-test $\mathbf{p}$ & FG1/MG1 \\
\hline $\mathrm{Ag}$ & $0.0160 \pm 0.0032$ & $0.0143 \pm 0.0032$ & 0.7 & $>0.05$ & 0.89 \\
\hline $\mathrm{Co}$ & $0.0374 \pm 0.0046$ & $0.0328 \pm 0.0042$ & 0.467 & $>0.05$ & 0.88 \\
\hline $\mathrm{Cr}$ & $0.502 \pm 0.051$ & $0.567 \pm 0.065$ & 0.441 & $>0.05$ & 1.13 \\
\hline $\mathrm{Fe}$ & $224 \pm 16$ & $172 \pm 22$ & 0.078 & $\leq \mathbf{0 . 0 5}$ & 0.77 \\
\hline $\mathrm{Hg}$ & $0.0439 \pm 0.0071$ & $0.0275 \pm 0.0046$ & 0.058 & $>0.05$ & 0.63 \\
\hline $\mathrm{Rb}$ & $7.96 \pm 0.61$ & $4.95 \pm 0.58$ & $\mathbf{0 . 0 0 1 1}$ & $\leq \mathbf{0 . 0 1}$ & 0.62 \\
\hline $\mathrm{Sb}$ & $0.109 \pm 0.012$ & $0.0880 \pm 0.0096$ & 0.174 & $>0.05$ & 0.81 \\
\hline $\mathrm{Sc}$ & $0.0052 \pm 0.0012$ & $0.0026 \pm 0.0017$ & 0.32 & $>0.05$ & 0.5 \\
\hline $\mathrm{Se}$ & $2.05 \pm 0.18$ & $1.86 \pm 0.27$ & 0.565 & $>0.05$ & 0.91 \\
\hline $\mathrm{Zn}$ & $102 \pm 6.6$ & $59.8 \pm 8.7$ & $\mathbf{0 . 0 0 0 8}$ & $\leq \mathbf{0 . 0 1}$ & 0.59 \\
\hline
\end{tabular}

Table 5: Differences between mean values (M $\pm \mathrm{SEM}$ ) of $\mathrm{Ag}, \mathrm{Co}, \mathrm{Cr}, \mathrm{Fe}, \mathrm{Hg}, \mathrm{Rb}, \mathrm{Sb}, \mathrm{Sc}, \mathrm{Se}$, and Znmass fraction (mg/kg, dry mass basis) in normal thyroid tissue of males and females aged $\leq 40$ years.

M - arithmetic mean, SEM - standard error of mean, t-test - Student's t-test, U-test - Wilcoxon-Mann-Whitney U-test, Statistically significant values are in bold.

\begin{tabular}{|c|c|c|c|c|c|}
\hline \multirow{2}{*}{ Element } & \multicolumn{4}{|c|}{ Thyroid tissue } & Ratio \\
\cline { 2 - 6 } & $\begin{array}{c}\text { Males (MG2) } \\
\mathbf{n = 2 8}\end{array}$ & $\begin{array}{c}\text { Females (FG2) } \\
\mathbf{n = 2 2}\end{array}$ & $\begin{array}{c}\text { Student's t-test } \\
\boldsymbol{p} \leq\end{array}$ & $\begin{array}{c}\text { U-test } \\
\boldsymbol{p}\end{array}$ & FG2/MG2 \\
\hline $\mathrm{Ag}$ & $0.0148 \pm 0.0019$ & $0.0138 \pm 0.0027$ & 0.753 & $>0.05$ & 0.93 \\
\hline $\mathrm{Co}$ & $0.0317 \pm 0.0031$ & $0.0644 \pm 0.0096$ & $\mathbf{0 . 0 0 5}$ & $\leq \mathbf{0 . 0 1}$ & 2.03 \\
\hline $\mathrm{Cr}$ & $0.548 \pm 0.070$ & $0.578 \pm 0.073$ & 0.767 & $>0.05$ & 1.05 \\
\hline $\mathrm{Fe}$ & $218 \pm 19$ & $279 \pm 31$ & 0.105 & $>0.05$ & 1.28 \\
\hline $\mathrm{Hg}$ & $0.0491 \pm 0.0082$ & $0.0370 \pm 0.0084$ & 0.311 & $>0.05$ & 0.75 \\
\hline $\mathrm{Rb}$ & $7.75 \pm 1.25$ & $7.05 \pm 0.63$ & 0.62 & $>0.05$ & 0.91 \\
\hline $\mathrm{Sb}$ & $0.107 \pm 0.018$ & $0.136 \pm 0.019$ & 0.276 & $>0.05$ & 1.27 \\
\hline $\mathrm{Sc}$ & $0.0049 \pm 0.0024$ & $0.0045 \pm 0.0014$ & 0.868 & $>0.05$ & 0.92 \\
\hline $\mathrm{Se}$ & $2.89 \pm 0.32$ & $2.48 \pm 0.34$ & 0.396 & $>0.05$ & 0.86 \\
\hline $\mathrm{Zn}$ & $104 \pm 10$ & $104.7 \pm 8.4$ & 0.98 & $>0.05$ & 1.01 \\
\hline
\end{tabular}

Table 6: Differences between mean values (M $\pm \mathrm{SEM}$ ) of $\mathrm{Ag}$, $\mathrm{Co}, \mathrm{Cr}, \mathrm{Fe}, \mathrm{Hg}, \mathrm{Rb}, \mathrm{Sb}, \mathrm{Sc}, \mathrm{Se}$, and Znmass fraction (mg/kg, dry mass basis) in normal thyroid tissue of males and females aged $>40$ years. M - arithmetic mean, SEM - standard error of mean, t-test - Student's t-test, U-test - Wilcoxon-Mann-Whitney U-test, Statistically significant values are in bold. 


\section{Discussion}

\section{Precision and Accuracy of Results}

Good agreement of the Ag, Co, Cr, Fe, Hg, Rb, Sb, Sc, $\mathrm{Se}$, and Zncontents analyzed by INAA-LLR with the certified data of CRM IAEA H-4 and IAEA HH-1 (Table 1) indicates an acceptable accuracy of the results obtained in the study of TE of the thyroid presented in Tables 26.

The mean values and all selected statistical parameters were calculated for tenTE (Ag, Co, Cr, Fe, $\mathrm{Hg}, \mathrm{Rb}, \mathrm{Sb}, \mathrm{Sc}, \mathrm{Se}$, and $\mathrm{Zn}$ ) mass fractions in thyroid of female and male (Table 2).

\section{Comparison with Published Data}

Values obtained for $\mathrm{Cr}, \mathrm{Fe}, \mathrm{Hg}, \mathrm{Rb}, \mathrm{Sb}, \mathrm{Sc}, \mathrm{Se}$, and $\mathrm{Zn}$ contents in the normal human thyroid (Table 3) agree well with median of mean values reported by other researches [25-35]. The obtained means for Ag and Co were almost one order of magnitude lower median of previously reported means but inside the range of means (Table 3). Data cited in Table 3 also includes samples obtained from patients who died from different non-endocrine diseases. A number of values for TE mass fractions were not expressed on a dry mass basis by the authors of the cited references. However, we calculated these values using published data for water (75\%) and ash (4.16\% on dry mass basis) contents in thyroid of adults $[27,54]$.

The range of means of $\mathrm{Ag}, \mathrm{Co}, \mathrm{Cr}, \mathrm{Fe}, \mathrm{Hg}, \mathrm{Rb}, \mathrm{Sb}, \mathrm{Sc}, \mathrm{Se}$, and $\mathrm{Zn}$ level reported in the literature for normal human thyroid vary widely (Table 3). This can be explained by a dependence of TE content on many factors, including the region of the thyroid, from which the sample was taken, age, gender, ethnicity, and mass of the gland. Not all these factors were strictly controlled in cited studies. Another and, in our opinion, leading cause of inter-observer variability can be attributed to the accuracy of the analytical techniques, sample preparation methods, and insufficient quality control of results in these studies.

\section{Gender-Related Differences}

Strongly pronounced differences in $\mathrm{Co}, \mathrm{Rb}$, and $\mathrm{Zn}$ mass fraction were observed between female and male thyroid (Table 4). The mean Co mass fraction in female thyroids was almost 1.4 times higher while the means of $\mathrm{Rb}$ and $\mathrm{Zn}$ mass fractions were respectively $22 \%$ and $17 \%$ lower than in male thyroids. During the first 40 years of life (Age group 1) the situation with TE contents in female thyroids was some different than that for older females. In Age group 1 no statistically significant difference between the Co content in female and male thyroids was found, but differences between their $\mathrm{Rb}$ and $\mathrm{Zn}$ contents were detected (Table 5). In Age group 1 of females with mean age 30.9 years the $\mathrm{Rb}$ and $\mathrm{Zn}$ contents in thyroid were respectively38\% and $41 \%$ lower than in thyroid of males from the same age group. Moreover, in this age group a modest but statistically significant reduced level of Fe mass fraction in female thyroids was observed using the nonparametric Wilcoxon-Mann-Whitney $U$-test. For ages over 40 years (Age group 2) a statistically significant difference between the Co content in female and male thyroids was observed and the mean Co content in female thyroids was 2 times higher than that in male thyroids. In Age group 2 differences between the $\mathrm{Fe}, \mathrm{Rb}$ and $\mathrm{Zn}$ contents in thyroids of females and males, previously found in the Age group 1, was no longer evident.

Because the prevalence of SCHis 10-15 times more greater in women than in men, we can accept that the levels and relationships of TE mass fractions in male thyroids as more suitable (perhaps optimal) for normal function of the gland $[3,9]$. If so, we have to conclude that up to age 40 years there is a significant deficiency of $\mathrm{Rb}$ and $\mathrm{Zn}$ contents in female thyroid parenchyma, accompanied by a modest deficiency of Fe. In age over 40 deficiencies of $\mathrm{Fe}, \mathrm{Rb}$ and $\mathrm{Zn}$ contents in female thyroid disappear and an excess of Co is now seen.

Cobalt: Co is widely used in a bijouterie production. It may be one of the reasons of the higher level of this TE content in female thyroids than in that in male thyroids. Health effects of high Co occupational, environmental, dietary and medical exposure are characterized by a complex clinical syndrome, mainly including neurological, cardiovascular and endocrine deficits, including hypothyroidism $[55,56]$. Moreover, Co is genotoxic and carcinogenic, mainly caused by oxidative DNA damage by reactive oxygen species, perhaps combined with inhibition of DNA repair [57]. Therefore, an excessive Co level in the thyroid of elderly females might inhibit thyroid hormonal synthesis.

Iron: The low Fe level in the thyroid of young women compared with men can be attributed to physiological characteristics of the female body related to reproduction and pre-menopausal physiology [45].

Rubidium: As for $\mathrm{Rb}$, there is very little information about its effects in organisms. No negative environmental effects have been reported. $\mathrm{Rb}$ is only slightly toxic on an acute toxicological basis and would pose an acute health hazard only when ingested in large quantities [58]. $\mathrm{Rb}$ has some function in immune responce, probably by supporting cell differentiation $[59,60]$. Both potassium $(K)$ and $R b$ are in the first group of the periodic table. $\mathrm{Rb}$, like $\mathrm{K}$, seems to be 
concentrated in the intracellular space and transfered through membrane by the $\mathrm{Na}+\mathrm{K}+-\mathrm{ATPa} e$ pump.Thus, the low $\mathrm{Rb}$ level in the thyroid of women compared with men might reflect the reduced ratio "Volume of thyroid cells / Volume of follicular colloid" in the female thyroid. Thyroid function depends in part on the total volume of active thyroid cells. From this it might be concluded that the reduced level of active cells in the thyroids of women compared to men increases risk of hypothyroidism.

Zinc: $\mathrm{Zn}$ is a most essential TE for humans. Today more than 300 proteins and over 100 DNA-binding proteins that require $\mathrm{Zn}$ have been classified. $\mathrm{Zn}$ is required for the synthesis of thyroid hormones, and deficiency of this TE can result in hypothyroidism $[61,62]$. Thus, a Zn deficiency in female thyroid parenchyma observed in the present study may be one of the reasons for the higher incidence of SCH in females in comparison with males.

\section{Conclusion}

Our data indicate that there is a statistically significant gender-related difference between TE levels in thyroid tissue of females and males. The Co mass fraction is higher while the $\mathrm{Rb}$ and $\mathrm{Zn}$ mass fractions are lower in female thyroids compared with those in male thyroids. Subclinical hypothyroidism is amultietiological and multifactorial complex condition. The complete understanding of the role of inadequate levels of some TE in thyroid parenchyma in the etiology of $\mathrm{SCH}$ requires a global vision of their different mechanisms of action, which is not yet possible with the present state of knowledge. However, from the results of our study it follows that an involvement of inadequate contents of intra-thyroidal $\mathrm{Co}, \mathrm{Rb}$ and $\mathrm{Zn}$ in the etiology of female SCH may be assumed.

\section{Acknowledgements}

Authors are grateful to Dr. Yu. Choporov, Head of the Forensic Medicine Department of City Hospital, Obninsk, for supplying thyroid samples.

\section{Conflict of Interest}

There is no any financial interest or any conflict of interest.

\section{References}

1. Krassas GE, Poppe K, Glinoer D (2010) Thyroid function and human reproductive health. Endocr Rev 31(5): 702-755.
2. Verma I, Sood R, Juneja S, Kaur S (2012) Prevalence of hypothyroidism in infertile women and evaluation of response of treatment for hypothyroidism on infertility. Int J Appl Basic Med Res 2(1): 17-19.

3. Bjoro T, Holmen J, Krüger O, Midthjell K, Hunstad K, et al. (2000) Prevalence of thyroid disease, thyroid dysfunction and thyroid peroxidase antibodies in a large, unselected population. The Health Study of Nord-Trondelag (HUNT). Eur J Endocrinol 143(5): 639-647.

4. Vanderpump MP, Tunbridge WM (2002) Epidemiology and prevention of clinical and subclinical hypothyroidism.Thyroid 12(10): 839 847.

5. Biondi B, Cooper DS (2008) The clinical significance of subclinical thyroid dysfunction. Endocr Rev 29(1): 76-131.

6. Rodondi N, den Elzen WP, Bauer DC, Cappola AR, Razvi S, et al. (2010) Subclinical hypothyroidism and the risk of coronary heart disease and mortality. JAMA 304(12): 1365-1374.

7. Asvold BO, Vatten LJ, Bjøro T (2013) Changes in the prevalence of hypothyroidism: the HUNT Study in Norway. Eur J Endocrinol 169(5): 613-620.

8. Baumgartner $\mathrm{C}$, da Costa BR, Collet $\mathrm{TH}$, Feller $\mathrm{M}$, Floriani C, et al. (2017) Thyroid function within the normal range, subclinical hypothyroidism, and the risk of atrial fibrillation. Circulation 136(22): 21002116.

9. Khan MA, Ahsan T, Rehman UL, Jabeen R, Farouq S (2017) Subclinical hypothyroidism: frequency, clinical presentations and treatment indications.Pak J Med Sci 33(4): 818-822.

10. Battikhi MN (2018) Correlation between AMH and TSH in infertile women. EC Gynaecology 7(1): 1215.

11. Zaichick V, Choporov Yu (1996) Determination of the natural level of human intra-thyroid iodine by instrumental neutron activation analysis. Journal of Radioanalytical and Nuclear Chemistry 207(1): 153-161.

12. Zaichick V, Zaichick S (1997) Normal human intrathyroidal iodine. Sci Total Environ 206(1): 3956.

13. Zaichick V (1998) Iodine excess and thyroid cancer. J Trace Elem Exp Med 11(4): 508-509. 
14. Zaichick V (1998) In vivo and in vitro application of energy-dispersive XRF in clinical investigations: experience and the future. J Trace Elem Exp Med 11(4): 509-510.

15. Zaichick V, Iljina T (1998) Dietary iodine supplementation effect on the rat thyroid 131I blastomogenic action. In: Die Bedentung der Mengen- und Spurenelemente. 18. Arbeitstangung. Jena, Friedrich-Schiller-Universität, pp: 294-306.

16. Zaichick VY, Zaichick SV (1999) Energy-dispersive $\mathrm{X}$-ray fluorescence analysis of iodine in thyroid puncture biopsy specimens. J Trace Microprobe Tech 17(2): 219-232.

17. Zaichick V (1999) Human intrathyroidal iodine in health and non-thyroidal disease. In: New aspects of trace element research, Smith-Gordon and Nishimura, London and Tokyo, pp: 114-119.

18. Zaichick V (2000) Relevance of, and potentiality for in vivo intrathyroidal iodine determination. In Vivo Body Composition Studies. Ann N Y Acad Sci 904: 630-631.

19. Usha Menon V, Sundaram KR, Unnikrishnan AG, Jayakumar RV, Nair V, et al. (2009) High prevalence of undetected thyroid disorders in an iodine sufficient adult south Indian population. J Indian Med Assoc 107(2): 72-77.

20. Zimmermann MB, Boelaert K (2015) Iodine deficiency and thyroid disorders.Lancet Diabetes Endocrinol 3(4): 286-295.

21. Guo Y, Zynat J, Xu Z, Wang X, Osiman R, et al. (2016) Iodine nutrition status and thyroid disorders: a cross-sectional study from the Xinjiang Autonomous Region of China. Eur J ClinNutr 70(11): 1332-1336.

22. Shan Z, Chen L, Lian X, Liu C, Shi B, et al. (2016) Iodine Status and Prevalence of Thyroid Disorders After Introduction of Mandatory Universal Salt Iodization for 16 Years in China: A Cross-Sectional Study in 10 Cities. Thyroid 26(8): 1125-1130.

23. Zaichick V, Tsyb A, Vtyurin BM (1995) Trace elements and thyroid cancer. Analyst 120(3): 817821.

24. Zaichick V (2006) Medical elementology as a new scientific discipline. Journal of Radioanalytical and Nuclear Chemistry 269(2): 303-309.

25. Zhu H, Wang N, Zhang Y, Wu Q, Chen R, et al. (2010) Element contents in organs and tissues of Chinese adult men. Health Phys 98(1): 61-73.
26. Vlasova ZA (1969) Dynamics of trace element contents in thyroid gland in connection with age and atherosclerosis. Proceedings of the Leningrad Institute of Doctor Advanced Training 80: 135-144.

27. Katoh Y, Sato T, Yamamoto Y (2002) Determination of multielement concentrations in normal human organs from the Japanese. Biol Trace ElemRes 90(13): 57-70.

28. Salimi J, Moosavi K, Vatankhah S, Yaghoobi A (2004) Investigation of heavy trace elements in neoplastic and non-neoplastic human thyroid tissue: A study by proton - induced X-ray emissions. Iran J Radiat Res 1(4): 211-216.

29. Tipton IH, Cook MJ (1963) Trace elements in human tissue. Part II. Adult subjects from the United States. Health Phys 9: 103-145.

30. Reddy SB, Charles MJ, Kumar MR, Reddy BS, Anjaneyulu Ch, et al. (2002) Trace elemental analysis of adenoma and carcinoma thyroid by PIXE method.Nucl Instr Meth Phys Res B 196(3-4): 333339.

31. Ataulchanov IA (1969) Age-related changes of manganese, cobalt, coper, zinc, and iron contents in the endocrine glands of females. Problemy Endocrinologii 15(2): 98-102.

32. Boulyga SF, Zhuk IV, Lomonosova EM, Kievetz MK, Denschlag HO, et al. (1997) Determination of microelements in thyroids of the inhabitants of Belarus by neutron activation analysis using the $\mathrm{k} 0$ method. J Radioanal Nucl Chem 222(1-2): 11-14.

33. Boulyga SF, Becker JS, Malenchenko AF, HansJoachim Dietze (2000) Application of ICP-MS for multielement analysis in small sample amounts of pathological thyroid tissue. Microchimica Acta 134(3-4): 215-222.

34. Fuzailov Yu M (1981) Reaction of human and animal thyroids in the conditions of antimony subregion of the Fergana valley. In: IX All-Union Conference on Trace Elements in Biology. Kishinev, pp: 58-62.

35. Kvicala J, Havelka J, Zeman J, Nemecl J (1991) Determination of some trace elements in the thyroid gland by INAA. J Radioanal Nucl Chem 149(2): 267-274.

36. Zaichick V (1997) Sampling, sample storage and preparation of biomaterials for INAA in clinical medicine, occupational and environmental health. In: Harmonization of Health-Related Environmental 


\section{Women's Health Science Journal}

Measurements Using Nuclear and Isotopic Techniques, IAEA, Vienna, pp: 123-133.

37. Zaichick V (2004) Losses of chemical elements in biological samples under the dry ashing process. Trace Elements in Medicine 5: 17-22.

38. Zaichick V, Zaichick S (2000) INAA applied to halogen (Br and I) stability in long-term storage of lyophilized biological materials. J RadioanalNuclChem 244(2): 279-281.

39. Zaichick V, Zaichick S (1996) Instrumental effect on the contamination of biomedical samples in the course of sampling. Journal of Analytical Chemistry 51(12): 1200-1205.

40. Zaichick V, Tsislyak Yu V (1978) A simple device for bio-sample lyophilic drying. Laboratornoe Delo2: 109-110.

41. Zaichick V, Tsislyak Yu V (1981) A modified adsorptive and cryogenic lyophilizer for biosample concentrations. Laboratornoe Delo 2: 100-101.

42. Zaichick V, Zaichick S (1997) A search for losses of chemical elements during freeze-drying of biological materials. J Radioanal Nucl Chem 218(2): 249-253.

43. Zaichick V (1995) Applications of synthetic reference materials in the medical Radiological Research Centre. Fresenius Janal Chem 352(1-2): 219-223.

44. Zaichick S, Zaichick V (2010) The effect of age and gender on 37 chemical element contents in scalp hair of healthy humans. Biol Trace Elem Res 134(1): 41-54.

45. Zaichick S, Zaichick V (2011) The scalp hair as a monitor for trace elements in biomonitoring of atmospheric pollution. I J Env H 5(1/2): 106-124.

46. Zaichick S, Zaichick V (2011) The effect of age on $\mathrm{Ag}, \mathrm{Co}, \mathrm{Cr}, \mathrm{Fe}, \mathrm{Hg}, \mathrm{Sb}, \mathrm{Sc}, \mathrm{Se}$, and $\mathrm{Zn}$ contents in intact human prostate investigated by neutron activation analysis. J Appl Radiat Isot 69(6): 827833.

47. Zaichick S, Zaichick V (2012) Trace elements of normal, benign hypertrophic and cancerous tissues of the human prostate gland investigated by neutron activation analysis. J Appl Radiat Isot $70(1)$ : 81-87.

48. Zaichick V, Zaichick S (2013) INAA application in the assessment of $\mathrm{Ag}$, Co, $\mathrm{Cr}, \mathrm{Fe}, \mathrm{Hg}, \mathrm{Rb}, \mathrm{Sb}, \mathrm{Sc}, \mathrm{Se}$, and $\mathrm{Zn}$ mass fraction in pediatric and young adult prostate glands. Journal of Radioanalytical and Nuclear Chemistry 298(3): 1559-1566.

49. Korelo AM, Zaichick V (1993) Software to optimize the multielement INAA of medical and environmental samples. In: Activation Analysis in Environment Protection. Dubna, Russia; Joint Institute for Nuclear Research, pp: 326-332.

50. Zaichick V, Zaichick S(2017) Age-related changes of $\mathrm{Br}, \mathrm{Ca}, \mathrm{Cl}, \mathrm{I}, \mathrm{K}, \mathrm{Mg}, \mathrm{Mn}$, and $\mathrm{Na}$ contents in intact thyroid of females investigated by neutron activation analysis. Curr Updates Aging 1: 5.1.

51. Zaichick V, Zaichick S (2017) Age-related changes of $\mathrm{Br}, \mathrm{Ca}, \mathrm{Cl}, \mathrm{I}, \mathrm{K}, \mathrm{Mg}, \mathrm{Mn}$, and $\mathrm{Na}$ contents in intact thyroid of males investigated by neutron activation analysis. J Aging Age Relat Dis 1(1): 1002.

52. Zaichick V, Zaichick S (2017) Age-related changes of some trace element contents in intact thyroid of males investigated by energy dispersive X-ray fluorescent analysis. MOJ GerontolGer 1(5): 00028.

53. Zaichick V, Zaichick S (2017) Age-related changes of some trace element contents in intact thyroid of females investigated by energy dispersive X-ray fluorescent analysis.Trends in Geriatric Healthcare 1(1): 31-38.

54. Schroeder HA, Tipton IH, Nason AP (1972) Trace metals in man: strontium and barium. J Chron Dis 25(9): 491-517.

55. Leyssens L, Vinck B, Van Der Straeten C, Wuyts F, Maes L (2017) Cobalt toxicity in humans-A review of the potential sources and systemic health effects Toxicology 387: 43-56.

56. Yu R (2017) Cobalt Toxicity, An overlooked Cause of Hypothyroidism. J Endocrinol Thyroid Res 1(3): $1-4$

57. Simonsen LO, Harbak H, Bennekou P (2012) Cobalt metabolism and toxicology--a brief update. Sci Total Environ 432: 210-215.

58. Johnson GT, Lewis TR, Wagner WD (1975) Acute toxicity of cesium and rubidium compounds. Toxicol Appl Pharmacol 32(2): 239-245.

59. Jones JM, Yeralan O, Hines G, Maher M, Roberts DW et al. (1990) Effects of lithium and rubidium on immune responses of rats. Toxicol Lett 52(2): 163168.

60. Petrini M, Vaglini F, Carulli G, Azzara A, Ambrogi F, et al. (1990) Rubidium is a possible supporting 
element for bone marrow leukocyte differentiation. Haematologica 75(1): 27-31.

61. Betsy A, Binitha MP, Sarita S (2013) Zinc Deficiency Associated with Hypothyroidism: An Overlooked Cause of Severe Alopecia. Int J Trichology 5(1): 4042.
62. Baltaci AK, Mogulkoc R (2017) Leptin, NPY, melatonin and zinc levels in experimental hypothyroidism and hyperthyroidism: the relation to zinc.Biochem Genet 55(3): 223-233. 